\title{
СОПОСТАВИТЕЛЬНАЯ ДИФФЕРЕНЦИАЦИЯ ПУБЛИЧНЫХ И ЧАСТНЫХ ИНТЕРЕСОВ КАК ФАКТОР ОТРАСЛЕВОЙ ЮРИДИЧЕСКОЙ ИНСТИТУЦИОНАЛИЗАЦИИ ЯВЛЕНИЯ ПУБЛИЧНОЙ СОБСТВЕННОСТИ
}

\begin{abstract}
Аннотация: Работа отражает результаты проведенного автором исследования вопроса о свойствах и конкретном содержании публичных интересов, выступающих основанием феномена публичной собственности. В основе проводимого сопоставления находится объективное существование в общественной жизни лишь двух типов социильных интересов - частных и публичных, а также исходная посылка, состоящая в наличии как сущностных различий, так и неразрывной дихотомической взаимосвязи публичного и частного начал сочиальной жизни. Постановка проблемы осуществляется в контексте необходимости определения правовой природы публичных интересов и, как следствие, правовой природы социальных явлений, в основании которых указанные интересы находятся. На базе аксиологического подхода к оценке правовых явлений делается вывод о том, что содержание публичных интересов фокусируется вокруг таких социальных иенностей, которые имеют определяющее значение для существования общества, его идентичности и последовательного развития; суммарное выражение этих ценностей в его наиболее абстрактном определении позволяет говорить о существовании некоего коренного публичного интереса, который служит своего рода «инстинктом самосохранения» определенного социчума (нации). Содержание публичных интересов, выступающих действительным основанием феномена публичной собственности, предопределяет, таким образом, бытийнье очертания данного феномена, его конкретно-историческое сочиальное предназначение. В частности, обосновывается тезис о том, что объективные свойства публичных интересов позволяют говорить об их сугубо конституцчионно-правовой природе, и, как следствие, о конституцуионно-правовой природе тех социальньх феноменов, в основании которых такие интересы непосредственно находятся.

Ключевые слова: Публичные интересы, публичная собственность, публичная власть, публичность, сочиокультурные цеенности, правовая аксиология, общество (нация), конституция, конституционное право, властеотношения. Abstract: This work reflect the result of conducted research on the issue of properties in a specific content of public interests acting as grounds for the phenomenon of public property. The comparison is based on the objective existence of only two types of social interest in public life - private and public, as well as the point of reference that consists in presence of both, substantial differences, and inseparable dichotomous correlation of public and private origins of social life. Statement of the problem takes place in the context of the need to define the legal nature of public interest, and subsequently the legal nature of social phenomena, which serve as the basis for the interests in question. The author justifies the thesis that objective qualities of the public interests allow us to speak of a strictly constructive legal nature, and thus of constructive legal nature of social phenomena that serve as direct basis for such interests.
\end{abstract}

Keywords: Nation, legal axiology, sociocultural values, public involvement, public authority, public domain, public interests, constitution, constitutional law, authoritative relations.

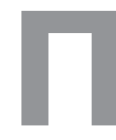

ризнание факта существования в общественной жизни, по существу, лишь двух типов социальных интересов - частных и публичных, - равно как и отсутствия между ними непреодолимой грани, служит побудительным мотивом к более предметному обсуждению их отличительных свойств, прежде всего, в содержательном отношении. Исследование содержания публичных интересов приобретает еще бо́льшую значимость, если рассматривать их как непосредственное социальное основание феномена публичной собственности: по сути, содержание публичных интересов и их иерархическая дифференциация в этом случае становятся фактором онтологической парадигмы публичной собственности, позволяя получить рельефное видение социального предназначения последней и определить целевые доминанты правового регулирования соответствующей сферы общественной жизни.

Если исходить из того, что «публичный» и «частный» являются контрарными характеристиками интересов, то в поиске различий между ними следует отталкиваться от социальных оснований, на которых вообще строятся бинарные оппозиции «личность - 
общество», «личность - государство» и «общество - государство». В этом случае ряд доктринально выделяемых различий между публичными и частными интересами мог бы, предположительно, выглядеть нижеследующим образом.

1). Частный интерес, вовлеченный в орбиту правового регулирования (т.е. будучи социально признан и квалифицирован в качестве юридически значимого), всегда имеет персонифицированную связь с индивидом или группой индивидов. Публичный интерес в своей основе не имеет персонифицированной связи с индивидами или их группами; в противном случае нарушалось бы свойство его универсальности. Таким образом, публичный интерес всегда лежит в плоскости коллективных представлений об общественном благе, справедливости и несправедливости (и т.д.), а потому не может определяться во взаимосвязи с системой мировоззренческих координат отдельно взятых индивидов.

2). Частный интерес для того, чтобы приобрести юридическое значение, должен быть объективирован. Необходимость такой объективации связана с тем, что существование частного интереса и, в том числе, его социальная полезность (или, как минимум, безвредность) должны быть признаны в нормах позитивного права. Это свойство любого частного интереса обусловлено известной аксиомой о том, что права и свободы одного лица заканчиваются там, где начинаются права и свободы другого лица. Но, разумеется, изложенная посылка может встретить возражение с точки зрения теории естественных прав. Однако, как известно, к естественным правам любого человека могут быть отнесены лишь те, которые служат удовлетворению самых первичных, фундаментальных потребностей личности, без которых невозможным было бы само ее существование. Стало быть, в силу данного обстоятельства сами естественные права имеют в основе своей лишь публичный интерес, ибо принадлежат они всем и каждому (без набора прав и свобод, признаваемых естественными, невозможно было бы существование и развитие человечества в целом).

В силу того, что публичный интерес в своей основе не имеет персонифицированной связи с индивидами или их группами, он, напротив, в отличие от частного интереса, способен приобрести правовое признание и правовую защиту независимо от того, имеет он в большей или меньшей степени определенную объективацию или не имеет ее вовсе. Публичный интерес может существовать независимо от того, закреплен он или нет в нормах позитивного права, поскольку соприкасается с плоскостью признанных и укоренившихся в обществе идеалов и антипатий, а чаще всего и «произрастает» из этой среды. Если обратиться к постулатам теории естественного права, то, поскольку единственным источником публичной власти в государстве всегда выступает лишь народ этого государства, ни одна из установленных государством норм позитивного права не сможет обрести в общественном восприятии «право на жизнь», если она находится в противоречии с публичным интересом (а точнее, его социальными основаниями - представлениями о должном и недолжном, справедливом и несправедливом, и т.д.). Конечно, при помощи инструментов позитивного права можно «записать на бумаге» совершенно любые правила и порядки, однако смысл права в его исполнении и, по возможности, исполнении добровольном. Соответственно, емкость публичного интереса такова, что он всегда первичен по отношению к позитивному праву, ибо и само позитивное право по своему содержанию должно быть направлено к удовлетворению публичных нужд.

3). Отмеченный выше признак любого частного интереса, заключающийся в необходимости его объективации при помощи норм позитивного права, позволяет выявить еще одно закономерное различие между частными и публичными интересами. Частный интерес для того, чтобы быть вовлеченным в орбиту правового регулирования, должен быть с большей или меньшей степенью определенности формально-юридически или доктринально закреплен при помощи словесно-логических описаний.

Собственно, указание на данную особенность частных интересов связано с тем, что право как социальный феномен представляет собой, прежде всего, текст; следовательно, всё, чего касается право как регулятор общественной жизни, имеет действительное или потенциальное текстовое выражение. В этой связи Ю. Ю. Ветютнев отмечает: «...наглядная характеристика права состоит в том, что оно обладает ярко выраженным текстуальным характером, то есть представляет собой знаковую систему...Не существует таких явлений, событий, процессов, которые являлись бы правовыми объективно, по природе своей, вне особого способа письменного закрепления» [7, с. 68-69]. И, подытоживая, он констатирует: «Разумеется, вся правовая реальность не может быть сведена к корпусу письменных источников, однако все ее «неписаные» компоненты являются сугубо производными и подчиненными, они не обладают автономным и самодостаточным бытием в отрыве от порождающего их текста. Например, юридическая сделка может быть совершена в устной форме, однако это возможно лишь благодаря юридиче- 
DOI: $10.7256 / 1811-9018.2015 .6 .15344$

При цитировании этой статьи сноска на dоі обязательна

\section{Право и политика 6 (186) • 2015}

скому предписанию, содержащемуся в писаном тексте Гражданского кодекса» [7, с. 69].

Таким образом, частные интересы, реализуемые в определенных регулируемых правом общественных отношениях, в силу отмеченного свойства права как текста всегда подлежат более или менее детализированному предметному отражению в нормах права сквозь призму устанавливаемых субъективных прав и корреспондирующих им юридических обязанностей.

В отличие от частных интересов, интересы публичные (по соображениям, приведенным выше касательно их объективации в праве) способны пользоваться юридическим признанием и правовой защитой независимо от того, имеют ли они внешнее формально-юридическое закрепление. Публичные интересы чаще всего являются настолько емкими по своему содержанию и диапазону возможных проявлений в жизни людей, что не поддаются точному описанию при помощи традиционного юридического синтаксиса по схеме «права - обязанности». Следовательно, публичные интересы, выводимые нередко из «живущих» в обществе представлений о благе и вреде, нравственном и безнравственном, справедливом и несправедливом (и т.д.), находят ближайшее свое словесно-логическое выражение, насколько оно является возможным, в нормах конституции государства, а также в актах конституционно-правовой отраслевой принадлежности, будучи почти полностью сокрытыми от нас, когда речь идет об отраслях права, рассчитанных, прежде всего, на юридическое упорядочение соотношения интересов частных.

4). Частные интересы, вводимые в орбиту правового регулирования, являются отражением существующего в конкретном обществе соотношения личности, общества и государства (если учесть, что эти интересы закрепляются нормами позитивного права, «рождаемого» в ходе осуществления государством правотворческой функции). Соответственно, частные интересы могут иметь различную отраслевую юридическую принадлежность, а если речь идет о частных интересах, которые пока не введены в рамки правового поля, - соответственно, вообще не иметь какой-либо отраслевой принадлежности. Эта отличительная черта частных интересов может быть объяснена также тем, что их многообразие, в конечном счете, обусловлено как широким кругом носителей указанных интересов, так и множественностью сфер общественной жизни, в которых частные интересы возникают. С этих позиций частные интересы, даже будучи сформулированы в предельно обобщенном своем выражении, в любом случае являются гораздо более многообразными, чем интересы публичные.
Публичные интересы, которые, как было показано выше, выступают явлением относительно автономным по отношению к позитивному праву, всегда служат мерилом социальной приемлемости закрепляемых позитивным правом интересов частных. С этой точки зрения публичный и частный интересы не только не могут противопоставляться друг другу, но и должны, в итоге, диалектически коррелировать в рамках правового регулирования общественной жизни. Соответственно, по «присутствию» или «отсутствию» в праве норм, рассчитанных на удовлетворение частного интереса (как было предложено еще Ульпианом [24, с. 4]), не только невозможно однозначно установить границу между правом частным и правом публичным, но и следует констатировать наличие в большей или меньшей степени выраженных проявлений публичных интересов в совершенно любой правовой норме, действующей в обществе.

Стало быть, публичные интересы благодаря своему проявлению (присутствию) в абсолютно любых сферах общественной жизни могут иметь единственно только конституционно-правовую природу, т.к. только отрасль конституционного права, как и лежащий в ее основании верховный правовой акт - конституция, - в силу самой своей сути и предназначения незримо проникает во все без исключения другие отрасли права и нормативные установления [5, c. $70-71 ; 18$, c. $153-155 ; 19$, с. $104-119 ; 31$, с. $25-30]$.

5). Описанные выше отличительные свойства публичных интересов в условиях провозглашенного правового государства делают необходимым постоянное соизмерение юридически значимых и, нередко, фактических действий тех, кто признан обществом в качестве субъектов реализации публичных интересов (в том числе, и тех, кто определяет правовую политику), c «живущими» в обществе представлениями о благе и пользе, нравственном и безнравственном, справедливом и несправедливом (и т.д.), т.е. с укоренившимися в общественном сознании идеалами и ожиданиями носителя этих публичных интересов (социума). Такое соизмерение достигается за счет наличия у публичных интересов и, как следствие, у всех процессов, связанных с их реализацией, свойства публичности, которое указывает на наличие юридически небезразличной вовлеченности всех или многих в те сферы общественной жизни, в которых реализуются соответствующие публичные интересы. При этом публичность как свойство публичных интересов и складывающихся вокруг них общественных отношений не следует отождествлять с такими понятиями, как гласность, открытость, «прилюдность»: социальной практике известна масса ситуа- 
ций, когда публичные интересы могут быть соблюдены и реализованы только при условии сохранения охраняемой законом тайны. В указанных случаях социум, будучи носителем публичных интересов, осуществляет соизмерение действий уполномоченных субъектов с существующими социальными ожиданиями и идеалами «по результату» этих действий. Соответственно, указанные «результаты», в силу свойства публичности, раньше или позже (но в любом случае) должны быть раскрыты обществу или стать известны широкому, индивидуально не определенному кругу лиц непроизвольным, случайным образом.

В отличие от интересов публичных, частным интересам, а равно и процессу их реализации в конкретных общественных отношениях, не присуще свойство публичности. Иными словами, социум не измеряет соотносимость действий конкретного индивида с укоренившимися в обществе идеалами и ожиданиями. Правда, следует заметить, что данный тезис справедлив лишь при условии, что содержание и направленность частного интереса и(или) процесс его реализации не приводят к нарушению требований позитивного права, установление (сотворение) которых, как было показано выше, в свою очередь всегда осуществляется в публичных интересах. Если частный интерес по своему содержанию или в процессе его реализации начинает противоречить нормам позитивного права, то он тотчас вовлекается в орбиту действия интересов публичных, заключающихся в недопустимости деформации общественных идеалов и ожиданий под действием интереса отдельно взятого индивида (или их группы). Однако в этой связи частный интерес, вовлеченный в орбиту действия вышеуказанных публичных интересов, все же сам по себе не приобретает свойства публичности: публичность в складывающемся таким образом социальном действии касается здесь не самого частного интереса отдельного лица или группы лиц, идущего вразрез с нормами позитивного права, а относится к публичному интересу, состоящему, с одной стороны, в восстановлении, по возможности, нарушенного частным интересом социального порядка, а с другой стороны, на предотвращение возникновения подобных частных интересов (или способов их реализации) в будущем.

6). Частные интересы, ввиду их бесчисленного разнообразия, объективно затруднительно сгруппировать по определенному классификационному основанию. Кроме того, отсутствие у них такого свойства как публичность, не позволяет ранжировать частные интересы в зависимости от ее степени - ведь свойство как таковое вообще отсутствует. Но даже если и можно было бы говорить о какой-нибудь уместной группировке частных интересов, - например, по признаку согласованности в их содержании одной или нескольких воль отдельных индивидов (т.е. по способу формирования таких интересов), - то деление получилось бы в лучшем случае двухчленным: индивидуальные (личные) частные и коллегиальные (групповые) частные интересы. Другая возможная классификация частных интересов, как можно предполагать, в общих чертах повторяла бы систему современного права - по меньшей мере, в части тех ее отраслей, которые имеют дело с юридическим упорядочением соотношения частных интересов. Стало быть, попытки классификации частных интересов, как представляется, лишены какого-либо существенного практического смысла.

Напротив, публичные интересы, имея единую юридическую природу - конституционно-правовую, - и несмотря на их довольно абстрактный характер, а также отмеченные выше сложности их словесно-логического описания, тем не менее, могут быть дифференцированы по степени важности. Критерием, который позволяет дифференцировать значимость публичных интересов, как раз и выступает степень их публичности - свойства, характеризующего юридически небезразличную вовлеченность общества и его отдельных индивидуально не определенных групп в отношения, связанные с реализацией соответствующего публичного интереса. Группировка публичных интересов по степени их публичности позволяет не только определять оптимальные методы и модели правового регулирования общественных отношений, в которых соответствующие публичные интересы реализуются, но и избирать для этих целей наиболее подходящий юридический синтаксис правовых норм. Например, для закрепления всеобщих (национальных) публичных интересов характерно частое использование норм-принципов, норм-целей, норм-деклараций.

На основе данного критерия можно было бы последовательно выделить несколько видов (уровней) публичных интересов, действующих в обществе, присвоив каждому из видов в определенной степени условные, технические наименования:

а) всеобщие (национальные) публичные интересы, в отношения по реализации которых так или иначе вовлекаются все граждане государства (а в ряде случаев также и иностранные граждане, и лица без гражданства);

б) коллективные публичные интересы, связанные с общественными отношениями в политико-правовой сфере и присущие отдельным индивидуально не 
DOI: $10.7256 / 1811-9018.2015 .6 .15344$

При цитировании этой статьи сноска на доі обязательна

\section{Право и политика $6(186) \cdot 2015$}

определенным социальным общностям и группам, имеющим реальные возможности по активному участию в управлении делами общества и государства либо желающим такие возможности приобрести;

в) корпоративные публичные интересы, связанные с общественными отношениями в социально-экономической сфере и объединяющие различные индивидуально не определенные социальные общности и группы (условно выражаясь, социальные корпорации), имеющие реальные возможности по получению определенных государственных и муниципальных услуг, а также доступ к материальным, интеллектуальным и духовно-культурным благам, в т.ч. предоставляемым другими индивидами, либо желающие такие возможности приобрести.

Безусловно, выделенные выше особенности и основания дифференциации публичных интересов пока следует рассматривать, прежде всего, в качестве гипотезы, которая требует дополнительного обоснования и эмпирического подтверждения. При этом в продолжение изложенного остается, пожалуй, лишь выдвинуть еще и предположение о том, что сопряжение публичных и частных интересов в правовой реальности, в конечном счете, обусловлено существованием некоего коренного публичного интереса, присущего любому человеческому обществу во все времена. Такой коренной публичный интерес, характеризуясь крайней степенью абстрактности, думается, служит средоточием всех иных возможных социальных интересов, непосредственно и неразрывно связан (если руководствоваться аксиологическим подходом) с самой главной социальной ценностью - человеческой жизнью, и выполняет роль, образно выражаясь, камертона, который удерживает в упорядоченном состоянии все ритмы общественного развития.

Однако, определенную сложность в выявлении конкретного содержания публичных интересов создает то обстоятельство, что в отечественной юриспруденции пока не сложилось устойчивых традиций использования термина «публичный интерес» в научном обиходе. В действующем законодательстве России и судебной практике данное понятие встречается, но каким-либо образом не раскрывается; кроме того, в отдельных законодательных актах (например, в Гражданском и Земельном кодексах РФ) встречается указание на публичные нужды, содержание и признаки которых также остаются не раскрытыми ни в этих нормативных правовых актах, ни в судебной практике.

Анализ имеющихся научно-теоретических источников, соприкасающихся с проблемой определения содержания публичных интересов, показывает, что исследователи оперируют понятием «публичный интерес» как в единственном, так и во множественном числе. Однако, если затем они и отказываются от описательной характеристики публичных интересов, пытаясь сформулировать определенную теоретическую дефиницию, то стремятся представить такую дефиницию в ее наиболее концентрированном смысловом значении [12, с. $43-47 ; 20$, с. $92-99 ; 22$, с. $69-71 ; 28$, с.55; 29, с. 25]. В ряде случаев такие попытки опираются на весьма тщательно взвешенные эмпирические основания: например, Ю. А. Тихомиров определяет публичный интерес как «признанный государством и обеспеченный правом интерес социальной общности, удовлетворение которого служит условием и гарантией ее существования и развития» $[28$, с. 55$]$.

Если исходить из множественности и неравнозначности публичных интересов общества, то следует констатировать, что попытки выработать какое-либо универсальное представление о содержании публичного интереса могут иметь успех лишь постольку, поскольку речь идет о коренном публичном интересе. Последний, в свою очередь, должен находиться во главе иерархической пирамиды публичных интересов общества и, по большому счету, иметь свое бытие в любом социуме на всех без исключения этапах его эволюции. Все остальные публичные интересы, так или иначе, производны от него и приобретают свое конкретное смысловое значение в зависимости от ряда факторов. В частности, едва ли могут быть высказаны сколько-нибудь весомые опровержения того факта, что публичные интересы видоизменяются с течением социального времени; в этом проявляется их историческая изменчивость. Таким же образом можно утверждать, что конкретное смысловое значение публичных интересов предопределяется и конфигурацией социального пространства, т.е. зависит от факторов социальной стратификации, солидаризации различных социальных общностей и групп, территориально-климатических и иных столь же естественных условий существования конкретного общества или его определенной части.

Таким образом, искомая универсальная дефиниция публичного интереса, будучи относима лишь к самому верхнему уровню «пирамиды» публичных интересов - так называемому коренному публичному интересу, - так или иначе, должна содержать указание на такую социальную ценность, которая является жизненно важной для любого общества и на все времена. В этой связи закономерным выглядит вывод о том, что в качестве такой социиальной ияенности выступает $и$ 
может выступать лишь ситуация, условно говоря, «самосохранения» общества. Речь идет о таком состоянии общественной жизни, при котором обеспечены:

- сохранение соответствующей общности (социума, нации) как таковой, т.е. ее физическое сохранение, включая защищенность от насильственного изменения занимаемой ею территории;

- сохранение самоидентичности соответствующей общности (социума, нации), т.е. сохранение признаков ее социокультурной неповторимости, самобытности;

- $\quad$ сохранение направлений и темпов развития соответствующей общности (социума, нации) в планетарной системе координат социальной эволюции, включая возможность этой общности самостоятельно (вне связи с внешним насильственным воздействием или «внутренним» принуждением со стороны государственного аппарата) определять направления такого развития с учетом конкретноисторического контекста.

Соответственно, с учетом изложенного можно сформулировать следующую универсальную дефиницию: коренной публичный интерес - это интерес индивидуально не определенного человеческого сообщества (социума, нации), заключающийся в обеспечении его физического и социокультурного сохранения, а также поступательной эволюции в конкретно-историческом контексте.

Несложно заметить, что предложенное выше определение, имея в своей основе аксиологическое измерение фундаментальных основ социального бытия, тяготеет к естественно-правовой философской традиции. Возможно, именно поэтому подтверждения сформулированной дефиниции можно встретить даже в самых ранних трудах «отцов-основателей» школы естественного права [23, с. 166-168], а также в работах многих других видных представителей философской политико-правовой мысли [3, с. 27-28; 17, с. 27; 25, с. 40].

Однако, с учетом изложенного, закономерен вопрос о том, какова же юридическая природа публичных интересов и каким образом они взаимосвязаны (и взаимосвязаны ли?) с феноменом публичной собственности. Ведь именно решение данного вопроса позволит сделать вывод и о правовой природе самой публичной собственности, что является краеугольным моментом при решении подавляющего большинства (если не всех) вопросов, связанных с выбором ее правового режима, определением форм и методов ее правового регулирования и, более широко, модернизацией системы российского права.
Прежде всего, следует констатировать, что при обращении к проблеме юридической природы публичных интересов невольно напрашивается предположение о том, что природа их конституционно-правовая. Такое предположение и было сделано выше, отталкиваясь от объективно существующего характера юридической имплементации публичных интересов в «ткань» правового регулирования: было отмечено, что универсальный характер публичных интересов, влекущий, за редкими исключениями, невозможность применения для их словесно-логического описания традиционного юридического синтаксиса по схеме «права - обязанности», объективно предопределяет (в качестве наиболее уместной) ситуацию, когда весь комплекс ключевых публичных интересов, имея в виду, прежде всего, коренной публичный интерес и всеобщие (национальные) интересы, оказывается ближайшим и наилучшим образом выражен в тексте конституции государства и актах конституционного законодательства.

Вместе с тем, отражение в тексте конституции и актах конституционного законодательства смысла и содержания указанных ключевых публичных интересов само по себе еще не является достаточным основанием для вывода об их конституционно-правовой природе. Как известно, в конституциях государств и в актах конституционного законодательства закрепляется множество принципов, деклараций, целей, предопределяющих юридическую сущность осуществляемого в дальнейшем на их основе отраслевого правового регулирования. Следовательно, проверка истинности или ложности сформулированного выше предположения о конституционно-правовой природе публичных интересов должна осуществляться не в привязке к источникам их выражения в нормах позитивного права, а отталкиваясь от представлений о предмете отрасли конституционного права. Хотя, безусловно, данная задача - не самая простая, поскольку, как известно, в отечественной науке конституционного права пока отсутствует единодушие в подходах к определению предмета отрасли.

Анализ современной научной и учебной литературы по конституционному праву России и зарубежных стран позволяет прийти к выводу о том, что, как правило, представители конституционно-правовой науки, опираясь на результаты собственных исследований, наблюдений и размышлений, стремятся сформулировать собственные (авторские) определения предмета отрасли конституционного права, в которых они делают акцент на тех или иных признаках, считающихся ключевыми для идентификации и юридического обособления 
DOI: $10.7256 / 1811-9018.2015 .6 .15344$

При цитировании этой статьи сноска на доі обязательна

\section{Право и политика $6(186) \cdot 2015$}

общественных отношений, подлежащих конституционно-правовому регулированию $[1$, с. $22 ; 2$, с. $15-16$; 4 , c. $5 ; 8$, c. $7 ; 9$, c. $5 ; 10$, c. $11 ; 13$, c. $10 ; 15$, c. $3 ; 16$, c. $7 ; 21$, c. $23 ; 33$, с. 17]. При этом одной из наиболее выверенных и полных в вопросе определения предмета отрасли конституционного права с учетом современных реалий усложняющейся общественной практики представляется позиция Т. Я. Хабриевой и В. Е. Чиркина. Они отмечают, что «статичный подход с перечислением четырех сфер общественной жизни хотя и верен, но недостаточен. Он должен быть дополнен...динамикой, т. е. выявлением характера прямых и обратных связей (конституционное регулирование и реакция на него), указанием на основную цель этих связей (установление правовых основ для создания и распределения общественных ценностей) и на элементы (компоненты), между которыми они складываются (человек, различные коллективы, государство и общество). Поэтому... можно сказать, что конституция вправе называться современной (не хронологически, а по существу), если она регулирует основы общественных отношений: экономической, социальной, политической систем общества, его духовной жизни, правового статуса человека и гражданина, основы прямых и обратных взаимосвязей индивида-коллектива-государства-общества путем применения государственной власти (выделено мной. - М. Б.), используемой в конечном счете для создания и распределения социальных ценностей при сотрудничестве и состязательности различных сил общества» [32, с. 74].

При синтетическом обобщении весьма широкого разнообразия научных точек зрения, выраженных по проблеме предмета отрасли конституционного права, в качестве стержневого признака общественных отношений, регулируемых данной отраслью, можно выделить то обстоятельство, что эти отношения в массе являются властеотношениями. Данный признак, безусловно, может являться дискуссионным, но, как представляется, лишь применительно к той группе общественных отношений, регулируемых отраслью конституционного права, в рамках которой происходит установление и реализация сущностных черт статуса личности, имеющих принципиальное значение для последующего отраслевого регулирования «горизонтальных» (частных по своему характеру) взаимодействий юридически равных индивидов. В остальных случаях отношения, регулируемые отраслью конституционного права, предстают как отношения по поводу установления, организации и осуществления публичной власти в обществе. В этом же состоит и принципиальное отличие властеотношений, в основном образующих предмет отрасли конституционного права, и властеотношений, складывающихся в сфере административно-правового регулирования: структура властеотношений, входящих в предмет отрасли административного права, всегда предполагает положение индивидов, их групп, коллективов (в том числе и юридических лиц) подчиненное по отношению к государству; в рамках же властеотношений, в основном образующих предмет отрасли конституционного права, государство нередко само находится в положении, подчиненном (обязанном) по отношению к личности, социальным группам, коллективам, обществу в целом.

Соответственно, если исходить из того, что предмет отрасли конституционного права в основном образуют общественные отношения, складывающиеся по поводу установления, организации и осуществления публичной власти в обществе, то вывод о конституционно-правовой природе публичных интересов может быть подтвержден только при условии выявления их связи с публичной властью, выступающей, в свою очередь, главной инструментальной ценностью (аксиологической доминантой) отношений, регулируемых конституционным правом. Для выявления такой связи (если она всё же существует) необходимо кратко охарактеризовать выработанные в государствоведении подходы к пониманию власти вообще, как социального феномена, и властвования.

И здесь необходимо констатировать, что в отношении вопроса о сущности феномена власти палитра высказанных мнений, выработанных концепций и сформированных учений крайне разнообразна. Это неслучайно, поскольку власть относится к тому же ряду сложнейших социальных феноменов, что и государство, право, собственность, религия, мораль, этика и т.д. Поэтому для целей настоящей работы вполне логичной видится необходимость ограничиться лишь общей теоретической трактовкой власти, включающей такие ее признаки, которые с бо́льшими или меньшими вариациями отмечаются всеми исследователями.

Одна из наиболее обстоятельных концепций публичной власти, основанная на всестороннем анализе существующих в настоящее время учений в области государствоведения, представлена в трудах В. Е. Чиркина. Он, в частности, отмечает, что в «современной научной литературе власть рассматривается в различных аспектах: как состояние, как способность, как отношение (субъект - объект), как принадлежность (в юридической науке - принадлежность определенного органа государства), как функция и т.д.» [34, с. 10]. 
Резюмируя, В. Е. Чиркин указывает: «Общим моментом для большинства этих подходов является волевая характеристика власти. Для власти в человеческом обществе необходимы осознание отношений субъект - объект как власти, элемент внешнего принуждения (а не «внутреннего принуждения» по велению души и сердца), осознанная возможность повелевать и необходимость подчиняться» [34, с. 10]. В числе других сущностных характеристик публичной власти ученый также называет принуждение (в том числе проявляющееся в ряде случаев в форме насилия) и принадлежность публичной власти коллективу, под которым он понимает относительно стабильное сообщество людей, в котором власть объективно возникает из необходимости управления «общими делами», что, по сути, означает связанность этого сообщества наличием общих для всех входящих в него индивидов интересов.

Ф. И. Шамхалов формулирует схожую позицию по вопросу о сущности власти в обществе. Ссылаясь на видного социолога М. Вебера [6, с. 540], ученый пишет: «Под властью в самом широком значении этого слова, как правило, понимается способность ее субъекта отдельного человека, группы, сословия, руководства профсоюзной организации, крупной корпорации или заинтересованной группы - навязать свою волю другим людям, коллективам, организациям, распоряжаться и управлять их действиями, используя разного рода насильственные и ненасильственные средства и методы с тем, чтобы приспособить их поведение к своим собственным интересам» [35, с. 105]. И, акцентируя внимание на волевом аспекте власти, Ф. И. Шамхалов подытоживает: «...власть - это прежде всего система общественных отношений между теми, кто ею обладает..., и теми, на кого она распространяется...В этом плане власть есть присущее обществу волевое отношение между людьми» [35, с. 105].

Приводимый ряд научных суждений, основанных, прежде всего, на выделении волевой характеристики публичной власти, можно было бы продолжать. Однако доказательство наличия волевой составляющей публичной власти не является самостоятельной целью настоящей работы. Гораздо важнее в данном контексте обратиться к мысли о том, что публичный интерес является результатом волевых процессов выявления и определения соответствующих нужд; следовательно, публичные интересы и публичная власть имеют единый генетический источник происхождения, обеспечивающий процессы социального волеобразования. Это обстоятельство, в свою очередь, и служит доказательством того, что между публичными интересами и публичной властью существует имманентная взаимосвязь. Причем взаимосвязь неразрывная, неуничтожимая, что объясняется принципиальной нерасщепляемостью бытия их первоисточника - социума.

Неслучайными в этой связи выглядят суждения тех ученых, которые, исследуя государство, выступающее в современном мире «центровым» носителем публичной власти, стремятся рассматривать данный феномен как механизм упорядочивания и нахождения баланса между различными социальными интересами: по сути, такой подход к оценке социального предназначения государства основывается на понимании (или, по меньшей мере, допущении) существующей имманентной и неразрывной взаимосвязи между публичными интересами и публичной властью. Так, например, Ю. А. Тихомиров пишет: «Многообразная деятельность государства всегда сопряжена с решением проблемы интересов. В обществе существуют различные интересы - частные, корпоративные, групповые, национальные, профессиональные, локальные, государственные, наконец, международные. Их носителями являются слои общества и правящая элита, бизнес-структуры. И вполне естественно, что наблюдается противоречивое соотношение интересов, которое может быть устойчивым или переменным. Государство призвано учитывать различные интересы и находить ту меру их «публичной усредненности», которая позволяет сохранять согласие в стране и выполнять государственные дела» [27, с. 60].

Вместе с тем, отыскание доказательства того, что между публичными интересами и публичной властью существует имманентная взаимосвязь, само по себе еще не является достаточным для подтверждения или опровержения конституционно-правовой природы публичных интересов. Как известно, публичная власть имеет взаимосвязь с неисчислимым количеством социальных явлений, институтов и отношений, однако данное обстоятельство не является безоговорочным поводом для того, чтобы все эти явления, институты и отношения считать конституционно-правовыми. В этой связи ключом к решению проблемы правовой природы публичных интересов может являться лишь осмысление характера их взаимосвязи с публичной властью, т.е. отыскание ответа на вопрос о том, в чем именно эта взаимосвязь проявляется и что является первичным публичные интересы или публичная власть.

На первый взгляд может показаться, что первичный характер имеют именно публичные интересы, а не публичная власть, предназначение которой в обществе как раз и определяется необходимостью реализации 
DOI: $10.7256 / 1811-9018.2015 .6 .15344$

При цитировании этой статьи сноска на доі обязательна

\section{Право и политика $6(186) \cdot 2015$}

публичных интересов. Однако данное суждение справедливо лишь применительно к двум типам ситуаций, имевших место в истории человечества: к этапу консолидации (социализации) разрозненных индивидов, осознавших пользу от объединения усилий в решении определенных вопросов, представляющих интерес для каждого, и этапу революционной смены существующего общественного строя.

Вместе с тем, применительно к современной ситуации (и вообще любой ситуации, когда социум сформирован и в нем в «штатном» режиме функционирует публичная власть) взаимосвязь публичной власти и публичных интересов не может подразумевать лишь однонаправленное их воздействие друг на друга, когда публичная власть является лишь производной от предопределяющих ее предназначение публичных интересов. Феномен власти, сочетающий в себе волевой и принудительный моменты, подразумевает выполнение этой властью организующей функции в обществе. В результате, публичная власть, изначально возникнув в контексте определенных, сформировавшихся до ее зарождения общих интересов, приобретает впоследствии качество среды, генерирующей новые или видоизмененные публичные интересы и выступающей вместилищем механизмов их аксиологической систематизации и упорядочения. По этой причине вполне справедливым представляется распространенный в современном государствоведении взгляд, согласно которому государство (а именно оно в современных условиях является центральной фигурой в системе осуществления публичной власти и главным средоточием властных функций), однажды возникнув, приобретает относительную автономность от конституировавшего его общества и, более того, поднимается над ним. В этой связи Ф. И. Шамхалов отмечает: «...именно власть является тем стержнем, который объединяет людей в одно целое, делает из хаотического множества людей единое сообщество, имеющее свои особые интересы и волю к совместной жизни» [35, с. 102].
Соответственно, взгляд на публичную власть как на специфическую среду формирования, преобразования и существования публичных интересов позволяет говорить о двунаправленном, диалектическом характере взаимосвязи публичных интересов и публичной власти.

Восприятие публичной власти, с учетом ее волевых характеристик, в качестве среды, генерирующей и вмещающей публичные интересы, является, пожалуй, самым наглядным и убедительным доказательством конституционно-правовой природы публичных интересов. Публичная власть, будучи помещенной в смысловой контекст права как явления, имманентно сопутствующего процессам зарождения и эволюции государства, безусловно, имеет конституционноправовую, учредительную (если можно так выразиться) юридическую природу по отношению к любым феноменам, связанным с государственной организацией общества. А если так, то публичные интересы, по отношению к которым публичная власть постепенно становится средой, обеспечивающей их генерирование и развертывание вовне, не могут обладать никакой юридической природой, хоть сколько-нибудь отличающейся от правовой природы самой публичной власти.

Данный вывод, несмотря на то, что он, на первый взгляд, непосредственно касается лишь раскрытия правовой природы публичных интересов, является критически важным с точки зрения методологических оснований дальнейшего исследования публичной собственности. С учетом того, что публичные интересы образуют социальное основание отношений публичной собственности и выступают объективной причиной для выделения публичной собственности в качестве специфической юридической формы отношений собственности вообще, подтверждение конституционно-правовой (и никакой другой) природы публичных интересов неизбежно приводит и к выводу о конституционно-правовой природе публичной собственности.

\section{Библиография:}

1. Авакьян С. А. Конституционное право России. Учебный курс: Учебное пособие. В 2 т. Т. 1. - 5-е изд., перераб. и доп. М.: Норма: НИЦ ИНФРА-М, 2014. - 864 с.

2. Авдеенкова М. П., Дмитриев Ю. А. Конституционное право Российской Федерации: Курс лекций. 2-е изд. - М., 2004. - 728 с.

3. Алигьери Данте. Монархия. - М., 1999. - 192 с.

4. Баглай М. В. Конституционное право Российской Федерации. 4-е изд. - М.: Норма, 2005. - 816 с.

5. Бондарь Н. С. Проблемы конституционализации юридического образования в Российской Федерации / Конституция, конституционализм, конституционализация правовых систем: актуальное соотношение понятий и трендов : материалы науч. - практ. конф., посвященной 20-летию Конституции РФ. - Тверь, 2013. - С. 70 - 86.

6. Вебер М. Избранные произведения. - М.: Прогресс, 1990. - 808 с.

7. Ветютнев Ю. Ю. Аксиология правовой формы: монография. - М.: Юрлитинформ, 2013. - 200 с. 
8. Габричидзе Б. Н, Елисеев Б. П, Чернявский А. Г. Конституционное право современной России. - М., 2001. - 416 с.

9. Государственное право зарубежных социалистических стран / Под ред. В. Е. Чиркина и Б. Н. Топорнина. - М., 1976. - 270 с.

10. Государственное право зарубежных социалистических стран: Учебно-методическое пособие. - Свердловск, $1970 .-327$ с.

11. Даниленко Д. В. Основные направления эволюции современного конституционализма // Право и политика. 2009. № 9. - С. 1920 - 1928 .

12. Жмакина Т. Ю. Конституционные основания публичной собственности в Российской Федерации. Дисс...канд.юрид. наук. - М., РУДН, 2007. - 157 с.

13. Зиновьев А. В. Конституционное право России: проблемы теории и практики. - М.; СПб., 2000. - 416 с.

14. Калабекова С. В., Напсо М. Д. Сохранение этнокультурной самобытности как фактор реализации национальных интересов в условиях общества постмодерна // Право и политика. 2013. № 6. - С. 771 - 777.

15. Ковешников Е. М. Российское конституционное право. - М., 2002. - 224 с.

16. Колюшин Е. И. Конституционное (государственное) право России. - М., 1999. - 381 с

17. Коркунов Н. М. Русское государственное право. Т. І. Введение и общая часть / Изд-е 6-е, под ред. и с доп. М. Б. Горенберга. - СПб., 1908. - 623 с.

18. Кравец И. А. Формирование российского конституционализма (проблемы теории и практики). Дисс...Д-ра юрид.наук. - М., 2002. $-584 \mathrm{c}$.

19. Крусс В. И. Понятие, актуальность и формы конституционализации права // Вестник Тверского государственного университета. Серия «Право». 2012. № 19. - С. $104-119$.

20. Кряжков В. А. Публичный интерес: понятие, виды и защита // Государство и право. 1999. № 10. - С. 92 - 99.

21. Кутафин О. Е. Предмет конституционного права. - М., 2001. - 448 с.

22. Мазаев В. Д. Публичная собственность в России: конституционные основы. - М.: Городец, 2004. - 384 с.

23. Монтескье Ш. Л. О духе законов // Избранные произведения. - М., 1955. - 800 с.

24. Римское частное право: Учебник / Под ред. проф. И. Б. Новицкого и проф. И. С. Пере-терского. - М.: Юристъ, 1996. - 583 с.

25. Соловьев В. С. Право и нравственность. - Минск-М., 2001. - 190 с.

26. Субочев В. В. Право и его роль в обеспечении диалектического единства личных, общественных и государственных интересов // Право и политика. 2003. № 12. - С. 4 - 11.

27. Тихомиров Ю. А. Государство. - М., 2013. - 320 с.

28. Тихомиров Ю. А. Публичное право. - М., 1995. - 496 с.

29. Тотьев К. Ю. Публичный интерес в правовой доктрине и законодательстве // Государство и право. 2002. № 9. - С. 19-25.

30. Трухачев В. В. Национальные интересы России: приоритеты в реализации // Право и политика. 2010. № 3. C. $436-439$.

31. Хабриева Т. Я. Этапы и основные направления конституционализации современного российского законодательства // Журнал конституционного правосудия. 2013. № 6. С. 25 - 30.

32. Хабриева Т. Я., Чиркин В. Е. Теория современной конституции. - М.: НОРМА, 2007. - 320 с.

33. Чиркин В. Е. Конституционное право в Российской Федерации. - М., 2001. - 474 с.

34. Чиркин В. Е. Публичная власть. - М.: Юристъ, 2005. - 175 с.

35. Шамхалов Ф. Собственность и власть. - М.: Изд-во «Экономика», 2007. - 412 с.

\section{References (transliterated):}

1. Avak'yan S. A. Konstitutsionnoe pravo Rossii. Uchebnyi kurs: Uchebnoe posobie. V 2 t. T. 1. - 5-e izd., pererab. i dop. - M.: Norma: NITs INFRA-M, 2014. - 864 s.

2. Avdeenkova M. P., Dmitriev Yu. A. Konstitutsionnoe pravo Rossiiskoi Federatsii: Kurs lektsii. 2-e izd. - M., 2004. - 728 s.

3. Alig'eri Dante. Monarkhiya. - M., 1999. - $192 \mathrm{s.}$

4. Baglai M. V. Konstitutsionnoe pravo Rossiiskoi Federatsii. 4-e izd. - M.: Norma, 2005. - $816 \mathrm{~s}$.

5. Bondar' N. S. Problemy konstitutsionalizatsii yuridicheskogo obrazovaniya v Rossiiskoi Federatsii / Konstitutsiya, konstitutsionalizm, konstitutsionalizatsiya pravovykh sistem: aktual'noe sootnoshenie ponyatii i trendov : materialy nauch. - prakt. konf., posvyashchennoi 20-letiyu Konstitutsii RF. - Tver', 2013. - S. $70-86$.

6. Veber M. Izbrannye proizvedeniya. - M.: Progress, 1990. - $808 \mathrm{~s}$.

7. Vetyutnev Yu. Yu. Aksiologiya pravovoi formy: monografiya. - M.: Yurlitinform, 2013. - $200 \mathrm{~s}$.

8. Gabrichidze B. N, Eliseev B. P, Chernyavskii A. G. Konstitutsionnoe pravo sovremennoi Rossii. - M., $2001 .-416$ s.

9. Danilenko D. V. Osnovnye napravleniya evolyutsii sovremennogo konstitutsionalizma // Pravo i politika. 2009. № 9. - S. 1920 - 1928.

10. Zhmakina T. Yu. Konstitutsionnye osnovaniya publichnoi sobstvennosti v Rossiiskoi Federatsii. Diss...kand.yurid.nauk. - M., RUDN, 2007. - $157 \mathrm{~s}$.

11. Zinov'ev A. V. Konstitutsionnoe pravo Rossii: problemy teorii i praktiki. - M.; SPb., 2000. - $416 \mathrm{~s}$.

12. Kalabekova S. V., Napso M. D. Sokhranenie etnokul'turnoi samobytnosti kak faktor realizatsii natsional'nykh interesov v usloviyakh obshchestva postmoderna // Pravo i politika. 2013. № 6. - S. $771-777$.

13. Koveshnikov E. M. Rossiiskoe konstitutsionnoe pravo. - M., 2002. $-224 \mathrm{~s}$.

14. Kolyushin E. I. Konstitutsionnoe (gosudarstvennoe) pravo Rossii. - M., 1999. - 381 s. 
DOI: $10.7256 / 1811-9018.2015 .6 .15344$

При цитировании этой статьи сноска на dоі обязательна

\section{Право и политика 6 (186) 2015}

15. Korkunov N. M. Russkoe gosudarstvennoe pravo. T. I. Vvedenie i obshchaya chast' / Izd-e 6-e, pod red. i s dop. M. B. Gorenberga. $-\mathrm{SPb} ., 1908 .-623 \mathrm{~s}$.

16. Kravets I. A. Formirovanie rossiiskogo konstitutsionalizma (problemy teorii i praktiki). Diss...d-ra yurid.nauk. - M., 2002. - 584 s.

17. Kruss V. I. Ponyatie, aktual'nost' i formy konstitutsionalizatsii prava // Vestnik Tverskogo gosudarstvennogo universiteta. Seriya «Pravo». 2012. № 19. - S. 104 - 119.

18. Kryazhkov V. A. Publichnyi interes: ponyatie, vidy i zashchita // Gosudarstvo i pravo. 1999. № 10. - S. 92 - 99.

19. Kutafin O. E. Predmet konstitutsionnogo prava. - M., 2001. - 448 s.

20. Mazaev V. D. Publichnaya sobstvennost' v Rossii: konstitutsionnye osnovy. - M.: Goro-dets, 2004. - 384 s.

21. Montesk'e Sh. L. O dukhe zakonov // Izbrannye proizvedeniya. - M., 1955. - $800 \mathrm{~s}$.

22. Solov'ev V. S. Pravo i nravstvennost'. - Minsk-M., 2001. - $190 \mathrm{s.}$

23. Subochev V. V. Pravo i ego rol' v obespechenii dialekticheskogo edinstva lichnykh, obshchestvennykh i gosudarstvennykh interesov // Pravo i politika. 2003. № 12. - S. $4-11$.

24. Tikhomirov Yu. A. Gosudarstvo. - M., 2013. - $320 \mathrm{c}$.

25. Tikhomirov Yu. A. Publichnoe pravo. - M., 1995. - $496 \mathrm{s.}$

26. Tot'ev K. Yu. Publichnyi interes v pravovoi doktrine i zakonodatel'stve // Gosudarstvo i pravo. 2002. № 9. - S. 19 - 25.

27. Trukhachev V. V. Natsional'nye interesy Rossii: prioritety v realizatsii // Pravo i politika. 2010. № 3. - S. 436 - 439.

28. Khabrieva T. Ya. Etapy i osnovnye napravleniya konstitutsionalizatsii sovremennogo rossiiskogo zakonodatel'stva // Zhurnal konstitutsionnogo pravosudiya. 2013. № 6. S. 25 - 30.

29. Khabrieva T. Ya., Chirkin V. E. Teoriya sovremennoi konstitutsii. - M.: NORMA, 2007. - $320 \mathrm{~s}$.

30. Chirkin V. E. Konstitutsionnoe pravo v Rossiiskoi Federatsii. - M., 2001. - 474 s.

31. Chirkin V. E. Publichnaya vlast'. - M.: Yurist', 2005. - 175 s.

32. Shamkhalov F. Sobstvennost' i vlast'. - M.: Izd-vo «Ekonomika», 2007. - 412 s. 